\title{
Social Economic Responsibility and Financial Performance of Saccos in Mitooma District, Uganda
}

\author{
Kaijuka Benson $^{1} \quad$ Richard Mwirumubi ${ }^{1} \quad$ Faustino.L.Orach - Meza $^{2}$ \\ 1.School of Business Administration and Information Technology, Nkumba University, Kampala - Uganda \\ 2.School of Sciences, Nkumba University, Kampala - Uganda
}

\begin{abstract}
This study was set out to find out the effect of social economic responsibility activities on financial performance of Savings and Credit Cooperative Societies in Uganda, using a case study of Mitooma District, Western Uganda. A cross section and survey research design were used and data was collected from 150 respondents. The findings on the effect of social economic activities and financial performance revealed a significant relationship. In conclusion the results showed that corporate social responsibility (economic activities) was a significant predictor of financial performance. The recommendations were made which included the SACCOs to continue helping its members in resource mobilization so as to help members achieve their needs with easy, the SACCOs to make more attractive dividends to shareholders so as attract new members and retain old ones and the SACCOs to improve on the paying of attractive interest rates to savers to mobilize more savings
\end{abstract}

Keywords: corporate social responsibility, financial performance, social economic activities

DOI: $10.7176 / \mathrm{EJBM} / 13-21-02$

Publication date: November $30^{\text {th }} 2021$

\section{Introduction}

The seeds of CSR are traceable to the foundations of capitalism, the birth and rise of the corporate form of business organization. Its history may be traced in the turbulent rise of the corporation in the late 1800's through the turn of the century and into the progressive era and a new business-government relationship (Lane, 2018).

In the 1953, a seminal book "Social Responsibilities of the Businessman" was penned by Bowen (1953) where CSR was systematically and widely discussed on how organization should take social obligations. This led, Carroll to refer to Bowen as the 'Father of Corporate Social Responsibility'. (Carroll, 2008)

In the around 1980s, the definitions of CSR were widened. In the 1990s, the discussions of CSR expanded with new theories like that stakeholder theory and corporate social performance. The stakeholder theory that largely emphasized need for the company to cater for the needs of the society that go beyond those of shareholders only Decker (2014).

CSR in Africa has also recently gained heightened interest generally due to high levels of poverty and inequalities, particularly among those countries in which sustainable development challenges appear most intractable (Christensen \& Overdorft, 2000). In such countries, CSR has gained resonance among local communities and the general public. CSR is gaining currency among organizations in poor countries and increasingly in African enterprises and contexts (Cheruiyot, 2010), partially because of social legislation that is apparently less comprehensive and poorly enforceable. More knowledge on CSR is critical and urgent owing to Africa's unique situations. As such, critical developments in CSR could enable enterprises and other parties to exercise due diligence in their operations, processes, and formulate policy to ameliorate any adverse social effects. CSR is an issue that is increasingly capturing the interest and imagination of people in the business world.

In Uganda, there are many companies doing their business successfully but same time some registering a high numbers of business restructurings and failures. This restructuring can be witnessed in the banking sector and telecommunication companies like Nile bank to Barclays bank and now Absa then Cetel to Zein then Warld finally Airtel company and all this due a huge lack of Corporate Social Responsibility activities. Business failures and closure in Uganda has been almost registered in all the sectors like manufacturing, tourism, hotels industry, transport industry among others witnessed in businesses like newspapers of The Star of 1980, Ngabo of 1979, Taifa Uganda Empya of 1953, DboziLya Buganda of 1927, Focus of 1983, Muno of 1911 and Evening Mail of 2004, in banking industry like Crane bank, Uganda Cooperative Bank, Gold Trust Bank, in hotel industry like Sheraton hotel and also these have been also attributed to less involvement in corporate social responsibilities. Due to the needs of the society in Uganda and fear for companies to lose businesses, companies have come forward to play vital role by practicing CSR to improve people's quality of life and the country's economy as well. This include Financial institutions like DFCU Bank and Standard Chartered Bank Ltd and Savings and Credit Cooperatives Societies like Kyamuhunga Peoples SACCO, Mitooma Peoples SACCO and Mutara SACCO among others. CSR in Uganda among Savings and Credit Cooperatives Societies concentrates on priority issues such as poverty reduction, improving education, resource mobilization, savings and improved standards of living (Fombrum, 2005). 


\section{Definition of corporate social responsibility}

The EU Commission defines CSR newly as, "the responsibility of enterprises for their impacts on society". The Commission suggests that, "enterprises should have in place a process to integrate social, environmental, ethical human rights and consumer concerns into their business operations and core strategy in close collaboration with their stakeholders" (Cardan \& Darragh, 2004).

Corporate Social Responsibility can be defined as the process by which firms integrate social environmental concerns into their culture, decision making strategy and operations in a transparent and accountable manner, thereby creating wealth and improving society at large. In the era of globalization and liberalization the norms of doing business are changing rapidly in market dominated competitive economy. (Cull, Demirguc \& Morduch, 2006).

Corporate social responsibility can be explained as a combination of sustainable development and treating employees and the society within which companies operate in a responsible manner Cheruiyot, (2011).

According to Freeman et al, (2010) CSR also called corporate conscience, corporate citizenship, social performance or sustainable responsible business is a form of corporate self-regulation integrated into a business model. CSR policy functions as a built-in, self-regulating mechanism whereby a business monitors and ensures its active compliance with the spirit of the law, ethical standards and international norms. CSR is a process with the aim to embrace responsibility for the company's actions and encourage a positive impact through its activities on the environment, consumers, employees, communities, stakeholders and all other members of the public who may also be considered as stakeholders.

CSR can be defined as the "economic, legal, ethical, and discretionary expectations that society has of organizations at a given point in time". The concept of CSR means that organizations have moral, ethical, and philanthropic responsibilities in addition to their responsibilities to earn a fair return for investors and comply with the law. However, corporate executives have struggled with the issue of the firm's responsibility to its society. It was argued by some researchers that the Corporation's sole responsibility was to provide a maximum financial return to shareholders ( Carroll, 2008).

\section{Social economic activities}

An organization's responsibility; that is to say, an organization primarily objective of making profit and accumulating wealth for the shareholders. Thus meeting the primary objective of meeting shareholders needs as well as the needs to the community being integrated in to planning of the entity. Economic responsibility involves integrity, corporate governance, economic development of the community, transparency, prevention of bribery and corruption, payments to national and local authorities, use of local suppliers, hiring local labor and similar areas (Carroll, 2008).

Social economic activities is defined as a set of business and economic activities that are carried out within the private sphere by organizations that seek a general or social interest (or both) in accordance of the following principles.

- Persons and social objectives takes a precedent over capital.

- Independence from the public authorities

- Profits obtained from economic activity are mainly distributed based on the work or service carried out by the partners in regard to social objective of the organization.

- Fostering internal and social solidarity, promoting a commitment with local development, equal opportunities for men and women, social cohesion, the integration of persons risks of exclusion, generating a stable and quality employment, work life balance and sustainability (Tsoutsoura ,2004)..

Social economic activities is the social science and branch of economics that studies the interrelationship between the economic activity and social behavior. It analyses how the economy is affected by social norms, ethics, sentiments and other factors. Social economic activities draws its information from the fields of philosophy, history, sociology and political -science. It uses such information to examine how it influences consumer behavior, shapes buying trends and affects other activities within business and economics (Kolter, 2005).

According to Cheruiyot, (2011), Social economic development activities is the process of social and economic development in the society. It is measured with indicators of gross domestic product, life expectancy, literacy and levels of employment.

\section{Financial performance}

Financial performance is a subjective measure of how well a firm can use assets from the primary mode of business and generate revenues. It's a general measure of the firms overall health over a given period of time ( Saedi, 2015).

According to Shrivastava (2015) Financial performance is the process of understanding and reviewing financial statements to get the better understanding of the performance of the company.

Financial performance is a complete evaluation of a company's overall standing in categories such as assets, liabilities, equity, expenses, revenue and profitability. It is a measure through various business related formulas 
that allow users to calculate exact details regarding a company's effectiveness (Tsoutsoura ,2004).

Financial performance is the achievement of a company's monetary benefits for an entity for a certain period covering the collection and allocation of finance measured by capital adequacy, liquidity, solvency, efficiency, leverage and profitability (Fombrum, 2005).

In the study of Okwoma (2012) Financial performance management is total performance of an organization. Financial performance is a measure how well the firm uses its assets from operations. And there is no single measure to be used in defining Financial performance of a firm.

\section{LITERATURE REVIEW}

\section{Investment Made in Economic Activities on the Financial Performance}

In 2011, Harvard Business School Professor Micheal Porter - the King of business gurus put forward a radical proposition to global corporation that; "Businesses must reconnect company success with social progress," he wrote in the Harvard Business Review. "Shared value is not social responsibility , philanthropy or even sustainability, but a new way to achieve economic success. It is not on a margin of what companies do but at the centre,". He continued to assert that ; "We believe that it can give rise to the next major transformation of business thinking,". The idea of Porter was warmly embraced by the heads of some of the world's largest corporations - all of which have active corporate social responsibility and sustainability programs (Ranjan, 2019).

Turban (2016) says that corporate social responsibility related issues are important drivers of corporate image and reputation, which are major determinants of consumer satisfaction. Satisfied consumer tends to have intensive purchase behavior and also continue in future in shape of consumer retention (Ali et al, 2010). This is the important key for gaining sustainable sales revenues and business profits.

Based on the Triple Bottom Line Concept of Elkington (1997), a company should be responsible for its social, environmental as well as financial performance also known as "profit, people and planet" approach. This approach encourages a company to take both the contributions and impacts they make to the social, economic and environmental into account when measuring corporate performance. To follow this concept, corporations have started to look for a strategy which seeks to maximize both financial return and social good.

According to Arora \& Dharwadhkar (2011) "social responsibility is not limited to the present members of the society, but should also be expanded to its future members, as well as environment, since it will have implications for members of society both now and in the future". Organizations are not operating in vacuum and apparently, their operations will affect their external environment. Stakeholders provide Organizations with a range of resources such as capital, customers, employees, materials and legitimacy (Deegan, 2002). They also provide the "license to operate" to the Organizations in return for the provision of socially acceptable or legitimate, actions. To strengthen this social contract which allows organization to continue operations, they need to be socially responsible. This can be an underlying reason why we would expect food industries to be involved in corporate social responsibility and reporting it to society. Anyona (2005) also showed how CSR result in sustained competitive advantage "the contribution that CSR may have to financial performance is nowadays primarily related to qualitative factors, such as employee morale or corporate reputation".

Simon (2014) conducted a study on the effect of corporate social responsibility on financial performance of 100 top small and medium enterprises in Kenya. This is so mostly with the large corporations who are using it as a corporate positioning tool and have continued to enjoy high profits from positive market perception due to CSR. Whereas CSR is taken to have positive effect on financial performance, those opposed to it argue that CSR involves the undertaking of a set of actions which are potentially cost increasing. Whereas studies on effect of CSR on financial performance are intensive, the findings have been contradicting, concentrating on large firms and leaving SMEs out. This study sought to determine the effect of CSR on financial performance of small and medium sized enterprises in Kenya using the top 100 SMEs. The study used descriptive survey research design with data being obtained from secondary sources which were the published financial statements, Chairman's Statement and notes to the financial statements for five years period from 2009 to 2013. The data obtained was analyzed using SPSS version 21 with multiple regressions being used to show the relationship between dependent and independent variables. This study found CSR has significant positive effect on financial performance of small and medium sized enterprises in Kenya. The study also found that size of SME has significant effect on profitability where bigger SMEs have better financial performance than small ones. This can be attributed to the labor created by engaging the youth in their practices or the various benefits attracted by CSR engagement. SME industry was also found to affect financial performance with SMEs in service industry having highest financial performance followed by trading and manufacturing being least profitable as measured by return on assets. The study recommends for more investment in CSR as a way of boosting SMEs profitability (Simon, 2014). A company's first responsibility is its economic responsibility. This can be translated to mean that a company needs to be primarily concerned with turning a profit. This is for the simple fact that if a company does not make money, it won't last, employees will lose jobs and the company won't even be able to think about taking care of its social responsibilities. Before a company thinks about being a good corporate citizen, it first needs to make sure that it 
can be profitable.

\section{RESEARCH METHODOLOGY}

This study used a cross sectional research design and survey research design (Enukoha,2011). Survey research design is a sociological investigation that uses question based or statistical surveys to collect information about how people think or act. More so, survey is a method of collecting information by asking questions. In this study, numerical and descriptive data was obtained for generating both a quantitative and qualitative research dimension. The study population is 200 respondents (Board members and employees of SACCOs) Tusiime (2019) who had written about cooperatives in Mitooma District. Sample Size determined using Slovenes formula of 150 respondents out of 200 of the study population.

\section{RESEARCH FINDINGS}

\section{Response Rate}

The study targeted 150 respondents to provide the information of the study and all 150 questionnaires were distributed to the respondents who composed the sample size of the study. Out of the 150 distributed questionnaires, 150 usable questionnaires were returned giving a response rate of $100 \%$ which was acceptable for the study according to Sekaran (2003) since all the questionnaires were filled and brought back to the researcher.

Effect of investment made in Economic Activities on the financial performance of SACCOs in Mitooma district, Uganda.

Table 1 Showing the response on Economic Activities

\begin{tabular}{|c|c|c|c|c|}
\hline & Mean & SD & Rank & Interpretation \\
\hline \multicolumn{5}{|l|}{ ECONOMIC RESPONSIBILITIES } \\
\hline \multicolumn{5}{|l|}{ Economic empowerment } \\
\hline $\begin{array}{l}\text { The SACCO has improved peoples incomes through mobilizations } \\
\text { to start up small saving groups to improve their standards of living }\end{array}$ & 3.90 & .301 & 1 & Good \\
\hline $\begin{array}{l}\text { The SACCO pays attractive dividends to shareholders so as attract } \\
\text { new members and retain old ones }\end{array}$ & 3.75 & .433 & 17 & Good \\
\hline $\begin{array}{l}\text { The SACCO pays attractive fares to service providers so as attract } \\
\text { new members and retain old ones }\end{array}$ & 3.76 & .429 & 16 & Good \\
\hline $\begin{array}{l}\text { The SACCO pays attractive interest rates to savers to mobilize more } \\
\text { savings }\end{array}$ & 3.75 & .448 & 17 & Good \\
\hline $\begin{array}{l}\text { The SACCO pays attractive salaries to employees to retain and } \\
\text { attract productive workforce }\end{array}$ & 3.83 & .431 & 6 & Good \\
\hline $\begin{array}{l}\text { The SACCO pays favorable interest rates to lenders to be promote } \\
\text { good relations }\end{array}$ & 3.77 & .451 & 14 & Good \\
\hline $\begin{array}{l}\text { The SACCO pays service providers in time to get quality services } \\
\text { as well }\end{array}$ & 3.83 & .397 & 6 & Good \\
\hline $\begin{array}{l}\text { The SACCO pays interest rates to savers in time to encourage more } \\
\text { savings }\end{array}$ & 3.86 & .349 & 2 & Good \\
\hline $\begin{array}{l}\text { The SACCO pays attractive salary to employees to attract } \\
\text { competitive staff }\end{array}$ & 3.85 & .362 & 3 & Good \\
\hline $\begin{array}{l}\text { The SACCO pays interest rates to lenders that is on market rates to } \\
\text { remain competitive }\end{array}$ & 3.84 & .386 & 5 & Good \\
\hline $\begin{array}{l}\text { The SACCO fairly prices their loan products to attract more } \\
\text { customers }\end{array}$ & 3.79 & .442 & 13 & Good \\
\hline $\begin{array}{l}\text { The SACCO disburses loans faster to its members to have customers } \\
\text { meet their emergency needs }\end{array}$ & 3.77 & .451 & 14 & Good \\
\hline $\begin{array}{l}\text { The SACCO charges less ancillary costs when borrowing in order } \\
\text { not to exploit their customers }\end{array}$ & 3.83 & .426 & 6 & Good \\
\hline \multicolumn{5}{|l|}{ Extra financial services } \\
\hline $\begin{array}{l}\text { The SACCO caters for staff welfare at work place to create a } \\
\text { favorable working environment }\end{array}$ & 3.83 & .414 & 6 & Good \\
\hline $\begin{array}{l}\text { The SACCO give out subsidized products to members to increase } \\
\text { their incomes to improve their standards of living }\end{array}$ & 3.81 & .409 & 10 & Good \\
\hline $\begin{array}{l}\text { The SACCO offers financial literacy to its members to promote the } \\
\text { culture of saving and financial management }\end{array}$ & 3.81 & .424 & 10 & Good \\
\hline
\end{tabular}




\begin{tabular}{|l|l|l|l|l|}
\hline $\begin{array}{l}\text { The SACCO helps its members in resource mobilization so as to help } \\
\text { members achieve their needs with easy }\end{array}$ & 3.73 & .459 & 19 & Good \\
\hline $\begin{array}{l}\text { The SACCO provides employment opportunities to the local } \\
\text { community to reduce unemployment rates and improve the standards } \\
\text { of living }\end{array}$ & 3.80 & .418 & 12 & Good \\
\hline $\begin{array}{l}\text { The SACCO provides special loans to the marginalized groups to } \\
\text { reduce poverty levels and income inequalities }\end{array}$ & 3.85 & .363 & 3 & Good \\
\hline
\end{tabular}

Source: Primary data 2021

From the results on competences as economic activities, using indicators of economic empowerment and extra financial services.

From the table 1 above part one economic empowerment, The SACCO has improved peoples incomes through mobilizations to start up small saving groups to improve their standards of living (Mean $=3.90)$, the SACCO pays interest rates to savers in time to encourage more savings (Mean $=3.86$ ), the SACCO pays attractive salary to employees to attract competitive staff ( Mean $=3.85)$, the SACCO pays interest rates to lenders that is on market rates to remain competitive (Mean $=3.84$ ), the SACCO pays attractive salaries to employees to retain and attract productive workforce ( Mean $=3,83$ ), the SACCO pays service providers in time to get quality services as well ( Mean $=3,83$ ), the SACCO charges less ancillary costs when borrowing in order not to exploit their customers ( Mean $=3,83$ ), the SACCO fairly prices their loan products to attract more customers $($ Mean $=3.79$ ), the SACCO pays favorable interest rates to lenders to be promote good relations ( Mean = 3.77), the SACCO disburses loans faster to its members to have customers meet their emergency needs ( Mean $=3.77$ ), the SACCO pays attractive fares to service providers so as attract new members and retain old ones ( Mean = 3.76), the SACCO pays attractive dividends to shareholders so as attract new members and retain old ones $($ Mean $=3.75)$ and the SACCO pays attractive interest rates to savers to mobilize more savings ( Mean $=3.75$ )

On the other hand, the results on extra financial services revealed that the SACCO provides special loans to the marginalized groups to reduce poverty levels and income inequalities (Mean $=3.85$ ), the SACCO caters for staff welfare at work place to create a favorable working environment ( Mean $=3.83$ ), the SACCO give out subsidized products to members to increase their incomes to improve their standards of living ( Mean $=3.81$ ), the SACCO offers financial literacy to its members to promote the culture of saving and financial management (Mean $=3.81$ ), the SACCO provides employment opportunities to the local community to reduce unemployment rates and improve the standards of living $($ Mean $=3.80)$ and the SACCO helps its members in resource mobilization so as to help members achieve their needs with easy ( Mean $=3.73$ ).

The ECR construct is conceptualized in this thesis to extract information about the respondents' views about the SACCO's economic empowerment to the community. Nineteen items were adopted from the work related to (Loosemore \& Lim, 2017) and was measured a five-point Likert scale. As can be shown in Table 4.09, the mean for each item related to ECR construct ranges between $3.81( \pm 0.416)$, which indicates that the majority of respondents agree that their respective SACCOs have economically empowered the community

Table 2: Showing the response rate on response on Financial performance

\begin{tabular}{|l|l|l|l|l|}
\hline Items & Mean & SD & Rank & Interpretation \\
\hline $\begin{array}{l}\text { The SACCO makes enough profits for its sustainability due to } \\
\text { corporate social responsibility }\end{array}$ & 3.92 & .278 & 2 & Good \\
\hline The SACCO's returns on equity are promising & 3.89 & .339 & 3 & Good \\
\hline $\begin{array}{l}\text { The SACCO's income increases every year due to corporate social } \\
\text { responsibility (CSR) }\end{array}$ & 3.76 & .460 & 12 & Good \\
\hline $\begin{array}{l}\text { The SACCO's net income supersedes our operating cost due to } \\
\text { corporate CSR }\end{array}$ & 3.75 & .466 & 13 & Good \\
\hline The SACCO market share has improved due to CSR activities & 3.81 & .444 & 8 & Good \\
\hline Liquidity position of SACCO have improved due to CSR activities & 3.87 & .396 & 4 & Good \\
\hline $\begin{array}{l}\text { community deals and transact with SACCOs that are engaged in CSR } \\
\text { activities }\end{array}$ & 3.77 & .466 & 11 & Good \\
\hline $\begin{array}{l}\text { The SACCO has reduced on the operational costs due to CSR } \\
\text { activities }\end{array}$ & 3.83 & .445 & 5 & Good \\
\hline There is increased return on equity of SACCO due to CSR activities & 3.73 & .507 & 13 & Good \\
\hline The SACCO surplus is taking an upward trend due to CSR activities & 3.83 & .445 & 5 & Good \\
\hline $\begin{array}{l}\text { The SACCO offers new loans products thus attracting new } \\
\text { customers and more revenue due to CSR engagement }\end{array}$ & 3.98 & .337 & 1 & Good \\
\hline $\begin{array}{l}\text { There are increased chances of sustainability of SACCO due to CSR } \\
\text { activities }\end{array}$ & 3.75 & .463 & 13 & Good \\
\hline
\end{tabular}




\begin{tabular}{|l|l|l|l|l|}
\hline $\begin{array}{l}\text { The SACCO has better investment to help it keep liquid enough to } \\
\text { meet customers' demands }\end{array}$ & 3.82 & .481 & 7 & Good \\
\hline The SACCO meets industry debt to equity ration & 3.81 & .459 & 8 & Good \\
\hline $\begin{array}{l}\text { The SACCO pays well external loans like from Micro Finance } \\
\text { support centre limited and UCCFS }\end{array}$ & 3.78 & .447 & 10 & Good \\
\hline
\end{tabular}

The findings of Table 2: shows different scores using mean ranges on financial performance on different aspects.

According to financial performance the SACCO offers new loans products thus attracting new customers and more revenue due to CSR engagement ( Mean $=3.98$ ), the SACCO makes enough profits for its sustainability due to corporate social responsibility ( Mean $=3.92$ ), the SACCO's returns on equity are promising $($ Mean $=3.89)$, the Liquidity position of SACCO have improved due to CSR activities ( Mean $=3.87$ ), the SACCO has reduced on the operational costs due to CSR activities (Mean =3.83), the SACCO surplus is taking an upward trend due to CSR activities ( Mean =3.83), the SACCO has better investment to help it keep liquid enough to meet customers' demands ( Mean =3.82), the SACCO market share has improved due to CSR activities (Mean =3.81), the SACCO meets industry debt to equity ratio ( Mean $=3.81$ ), the SACCO pays well external loans like from Micro Finance support centre limited and UCCFS ( Mean $=3.78$ ), community deals and transact with SACCOs that are engaged in CSR activities ( Mean =3.77), the SACCO's income increases every year due to corporate social responsibility $(\mathrm{CSR})($ Mean $=3.76)$, the SACCO's net income supersedes our operating cost due to corporate CSR $($ Mean = $3.75)$, there is increased return on equity of SACCO due to CSR activities (Mean =3.75) and there are increased chances of sustainability of SACCO due to CSR activities (Mean =3.75),

The FP construct is conceptualized, in this thesis, to obtain information related to the respondents' perceptions financial performance of the organization she or he works for. Fifteen items were adopted from the work of (Grigore, 2010) were measured using a 5-point Likert scale. The results of the descriptive statistics in Table 2 indicate that the mean for the FP items ranged from $3.83( \pm 0.433)$. The results indicate that respondents were convinced that their organizations were in a good financial position

Relationship between investment made in economic involvement activities and financial performance of SACCOs in Mitooma district, Western Uganda.

Table 3: Shows the correlation between investment made in economic involvement activities and financial performance of SACCOs in Mitooma district, Western Uganda.

Correlations

\begin{tabular}{|c|c|c|c|}
\hline & \multicolumn{2}{|c|}{ Economic Environment Activities Financial Performance } \\
\hline \multicolumn{2}{|c|}{ Economic Environment ActivitiesPearson Correlation } & $\begin{array}{ll}1 \\
1\end{array}$ & $.324^{* *}$ \\
\hline 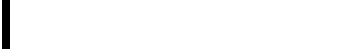 & Sig. (2-tailed) & & .000 \\
\hline & $\mathrm{N}$ & 145 & 137 \\
\hline Financial Performance & Pearson Correlation & $.324^{* *}$ & 1 \\
\hline & Sig. (2-tailed) & .000 & \\
\hline & $\mathrm{N}$ & 137 & 141 \\
\hline
\end{tabular}

**. Correlation is significant at the 0.01 level (2-tailed).

Source: Primary Data, 2021

According to the results from table 3 above, the PLCC (r) $0.324^{* *}$ value exceeds the critical PLCC (r) value of 0.087 . Thus at 0.05 significance level, the alternative hypotheses are accepted while the null hypotheses rejected. Therefore, it is concluded that there is a significant relationship between investment made in economic involvement activities and financial performance of SACCOs in Mitooma district, Western Uganda. This implies that without investment made in economic involvement activities, financial performance would not be effective on SACCOs in Mitooma district, Western Uganda.

\section{In conclusion}

The findings on the effect of economic activities and financial performance revealed a significant relationship. This is confirmation that SACCO offers new loans products thus attracting new customers and more revenue due to CSR engagement and that SACCO pays interest rates to savers in time to encourage more savings

\section{Recommendations}

The recommendation below was suggested.

- The SACCOs to continue helping its members in resource mobilization so as to help members achieve their needs with easy

- The SACCOs to make more attractive dividends to shareholders so as attract new members and retain old 
ones

- The SACCOs to improve on the paying of attractive interest rates to savers to mobilize more savings

\section{REFERENCES.}

Ali, I., Rehman, K.U., Yilmaz, A.K. \&Nazir, T.Y (2010).Effects of corporate social responsibility on consumer retention in cellular industry of Pakistan, African Journal of Business Management.Vol.4(4), Pp. 475-485.

Anyona, E. (2005) Relationship between Corporate Social Responsibility and Financial Performance of Commercial Bans in Kenya. Unpublished MBA Project, University of Kenya.

Arora, P., \& Dharwadkar, R. (2011). Corporate governance and corporate social responsibility (CSR): The moderating roles of attainment discrepancy and organization slack. Corporate governance: an international review, 19(2), 136-152.

Bowen, H.R (1953), Social Responsibilities of the Businessmen, New York.

Carroll, A.B. (2008), "A three-dimensional conceptual model of corporate performance", Academy of Management Review, Vol. 4, pp. 497-505.

Cheruiyot, E. (2010) Corporate Social Responsibility and financial performance of listed companies in KSE, Unpublished MBA Project, University of Kenya.

Christensen, C.M \& Overdorf M (2000).Meeting the Challenge of Disruptive Changes. Harvard Business Review, 78(2), 66-75.

Cull, R., Demirguc-Kunt, A. \& Morduch, J. (2006): Financial performance and outreach: a global analysis of leading micro banks, Policy Research Working Paper Series 3827, The World Bank.

Decker, O. S. (2004). Corporate social responsibility and structural change in financial Services, Managerial Auditing Journal 19 (6) 712-728

Enukoha. D.G. (2011). Research and Research Reporting Education and Policy Sciences. Nigeria: Akaa \& Akaa Graphics.

Fombrun, C. (2005). Building corporate reputation through corporate social responsibility initiatives: Evolving standards. Corporate Reputation Review. Vol. 8(1), Pp. 7-11.

Freeman, R. E., Harrison, J. S \& Wicks, A. C., Parmar, B. L., \& De Colle, S. (2010). Stakeholder theory: The state of the art. Cambridge University Press.

Grigore, G. (2010). Ethical and philanthropic responsibilities in practice. of the University of Personae. Economics, $10(3), 167-174$.

Kotler, P. \& Lee, N. (2005), Corporate Social Responsibility: Doing the Most Good for Your Company and Your Cause, Wiley, Hoboken, NJ.

Lane, P.J., Cannella, A.A. \& Lubatkin, M.H. (2018), "Agency problems as antecedents to unrelated mergers and diversification: Amihud and Lev reconsidered', Strategic Management Journal, Vol. 19 No. 6, pp. 555-78.

Okwoma, D. (2012); Relationship between Corporate Social Responsibility and Financial Performance of Commercial Bans in Kenya. published MBA Project, University of Kenya. 53

Ranjan, C. (2019). Strategic Management of Service - New Delhi Oxford University Press. Research, 67(3), 295 302.

Saeidi, S. P., \&Sofian, S. A. (2015). How does corporate social responsibility contribute to firm financial performance? The mediating role of competitive advantage, reputation, and customer satisfaction. Journal of Business Research, 68(2), 341-350.

Shrivastava, P. (2015), “Eccentric management for a risk society”, Academy of Management Review, Vol. 20, pp. 118-37.

Simon. K. (2014) The effect of Corporate Social Responsibility and Financial Performance of Small and Medium Enterprises in Kenya. Unpublished Masters Research of Business Administration, Kampala International University.

Tsoutsoura, M. (2004), Corporate Social Responsibility and Financial Performance. University of California

Turban, D. B. \& Greening, D. W. (2016).Corporate social performance and organizational attractiveness to prospective employees. Academy of Management Journal. Vol. 40, Pp.658-672.

Tusime, B. (2019). Cooperative Societies and Poverty Reduction in Greater Bushenyi, Uganda. MBA Project. Kampala International University, Uganda. 